\title{
Performance evaluation of household water treatment systems used in Kerman for removal of cations and anions from drinking water
}

\author{
Mohammad Malakootian ${ }^{1,2}$ - Najmeh Amirmahani ${ }^{1} \cdot$ Ghazal Yazdanpanah $^{1}$ • \\ Alireza Nasiri ${ }^{1} \cdot$ Ali Asadipour ${ }^{3} \cdot$ Ahmad Ebrahimi $^{4} \cdot$ Sodaif Darvish Moghaddam $^{5}$
}

Received: 12 December 2016/Accepted: 11 July 2017/Published online: 12 August 2017

(c) The Author(s) 2017. This article is an open access publication

\begin{abstract}
Increased awareness in society of the consequences of contaminants in drinking water has created a demand for household water treatment systems, which provide higher quality water, to spread. The aim of this study was to evaluate the performance of household water treatment systems used in Kerman for the removal of cations and anions. Various brands of home water treatment devices commonly used in Kerman were selected, with one device chosen from each brand for study. In cases in which the devices were used extensively, samples were selected with filters that had been changed in proper time, based on the device's operational instructions. The samples were selected from homes in the center and four geographical directions of Kerman. Then, sampling was conducted in three stages of input and output water of each device. For each of the samples, parameters were measured, such as chloride, sulfate, bicarbonate, calcium, magnesium, hardness, sodium, nitrate and nitrite $(\mathrm{mg} / \mathrm{L})$, temperature $\left({ }^{\circ} \mathrm{C}\right)$, and $\mathrm{pH}$. The average removal efficiency
\end{abstract}

Sodaif Darvish Moghaddam

sdmoghadam@kmu.ac.ir; sdmoghaddam@yahoo.com

1 Environmental Health Engineering Research Center, Kerman University of Medical Sciences, Kerman, Iran

2 Department of Environmental Health, School of Public Health, Kerman University of Medical Sciences, Kerman, Iran

3 Department of Medicinal Chemistry, Pharmaceutical Research Center, School of Pharmacy, Kerman University of Medical Sciences, Kerman, Iran

4 Private Clinical Laboratory Specialist, Kerman University of Medical Sciences, Kerman, Iran

5 Gastroenterology Hepatology Research Center, Kerman University of Medical Sciences, Kerman, Iran of different parameters by 14 brands in Kerman, which include chloride ions, sulfate, bicarbonate, calcium, magnesium, sodium, nitrites, nitrates, and total hardness, was obtained at 68.48, 85, 67, 61.21, 78.97, 80.24, 32.59, 66.83, and $69.38 \%$, respectively. The amount of sulfate, bicarbonate, chloride, calcium, magnesium, hardness, sodium, and nitrate in the output water of household water treatment systems was less than the input water of these devices, but nitrite concentration in the output of some devices was more than the input water and showed a significant difference $(p>0.05)$.

Keywords Performance evaluation - Chemical quality . Kerman water $\cdot$ Household water treatment systems

\section{Introduction}

Improving water quality in terms of physical, chemical, and biological is one of the priorities of basic human needs. Drinking water consumption is one way to supply the human body's necessary minerals. Some chemicals, such as pesticides and heavy metals, because of the danger of even small amounts, endanger human health. Therefore, increased awareness in society of the consequences of contaminants in drinking water has created a demand for household water treatment systems which provide higher quality water, and therefore has caused the supply of various kinds and large number of household water treatment systems (Mwabi et al. 2011; Tobin et al. 1981).

Undesirable chemical water quality can cause disorders, such as tooth decay, heart disease, digestive disorders, kidney disease, and high blood pressure. Hence, improving treatment of water resources can play a decisive role in reducing these diseases and their complications. Water- 
soluble salts are in cationic or anionic forms. Important cations in water are calcium, magnesium, sodium, iron, manganese, and potassium, and important anions are nitrite, nitrate, bicarbonate, sulfate, and chloride (Altura and Altura 1995; Amiri 2007; Ghee and Steel 1991; ISIRI 2009; Maier 2003; Saris et al. 2000; Sauvant and Pepin 2002; Hammer-Sr and Hammer-Jr 2007).

Water treatment systems at point of use (POU) by consumers regularly include the whole range of purification systems, including adsorption, membrane filtration, chlorination, UV lamps, etc., to remove pollutants from drinking water (Chaidez and Gerba 2004). Studies done on the efficacy of POU systems to remove pollutants in laboratory scale have shown that the removal rates of pollutants by these systems are desirable (Coulliette et al. 2013). Based on the World Health Organization's opinion, water treatment at the point of use is cost effective compared to other methods (Luby et al. 2008).

Because of ion exchange properties, zeolites have extensive uses. Due to the structure and chemical composition of natural zeolites, they can be applied in several research and applications fields, such as ion exchange, adsorption, and desorption of gases, and are also used as a catalyst (Belviso et al. 2014). The zeolite filter is used to remove hardness of water used in household consumption.

Depending on the type of resin, they can remove calcium and magnesium from water, and can add sodium or hydrogen to water. Accordingly, this phenomenon can cause increased salinity or acidity in water and in both cases, may cause or aggravate digestive problems (Yusof et al. 2010; Zhou and Boyd 2014).

Aluminum is a key factor for enhancing chemical absorption and performance improvements. Since aluminum has capacity $3^{+}$and silicon has capacity $4^{+}$, replacement of aluminum with silicon causes a reduction in the need for balancing cations (Corma and Garcia 2004). Charged cations balance alkali and alkaline earth metals, such as sodium, potassium, magnesium or calcium. Hydrogen cationic resins can remove all water cations, and anionic resins may also remove all water anions, such as silica (Mao et al. 1994; Wang and Peng 2010).

Miranzadeh and Rabbani (2010) in Iran (Kashan) evaluated the chemical qualities of input and output water of desalination devices. Esmailiyan and Nezamzadeh (2010) in Iran (Ahvaz) in their study showed that surfactant adsorption by zeolite and the production of surfactant-modified zeolite caused extensive changes in the properties of zeolite, and therefore caused changes in absorption of water anionic pollutants. Malakootian et al. $(2015,2016 \mathrm{a}, \mathrm{b})$ in Iran conducted researches on the removal of organic and inorganic pollutants, such as acetaminophen and tetracycline, by raw and modified zeolite. Zhou and Boyd (2014) in America in a study showed that mordenite and other zeolites are useful for the removal of ammonia nitrogen from pools. Hortiguela et al. (2013) in Spain in their study showed that natural zeolites are able to reduce fluoride concentration below the limit recommended by World Health Organization. Mwabi et al. (2011) in South Africa studied household water treatment systems used for the production of clean water in South Africa's low-income communities. Morrisa et al. (2008) in Britain evaluated the effect of water hardness on cardiovascular diseases. Yari et al. (2007) in Iran (Qom) examined the physical, chemical, and microbial qualities of treated-water desalination devices. Monarca et al. (2006) in Italy evaluated the effect of hardness, and calcium and magnesium levels on cardiovascular diseases.

According to research conducted, water treatment systems have the ability to remove minerals, such as magnesium, copper, chromium, fluoride, zinc, iron, selenium, manganese, phosphorus, potassium, and calcium (Yari et al. 2007; Miranzadeh and Rabbani 2010). Because of the popular belief that there is a relation between water purity and some gastrointestinal symptoms, such as bloating and constipation, this study was designed to evaluate the performance of household water treatment systems used in Kerman to remove cations and anions from drinking water.

\section{Materials and methods}

The study is a descriptive cross-sectional that was done in Kerman from January to June 2016 on household water treatment systems as a joint project of the Gastroenterology and Hepatology Research Center and the Environmental Health Engineering Research Center, Kerman University of Medical Sciences.

Several devices were selected randomly from all brands of household water treatment systems supplied in Kerman. In cases which the devices were used extensively, samples were selected with filters that had been changed in proper time, based on the device's operational instructions. The samples were selected from homes in the center of Kerman and also from outwards in the four geographical directions from the center of the city. The reason for this is that in Kerman water is pumped from four sources in different directions with different water quality to the distribution network. Then one sample was conducted of input and output of each device from a total of 30 different brands in homes from the center and four directions of Kerman. In three stages with an interval of 50 days, a total of 180 samples were tested. For each of the samples, some parameters, such as chloride, sulfate, bicarbonate, nitrate, and nitrite, by ion chromatographic method, sodium 
cations by flame photometer method, calcium and magnesium cations by flame atomic absorption spectrometry method, and total hardness by classic method, were measured. Temperature and $\mathrm{pH}$ were measured in situ. The averages of obtained figures from three experiments were calculated. Then the removal efficiency of each of the parameters was calculated, and the results were compared with latest Iran standards and World Health Organization guidelines. Finally, the removal efficiencies of cations and anions were determined for each device and they were then compared with each other. All stages of sampling and testing were done according to standard methods for the examination of water and wastewater, edition 21 (Eaton et al. 2005).

For weighing materials, $\mathrm{pH}$ determining, anions measuring, sodium measuring, and calcium and magnesium measuring, an electric scale (AEL-200, Japan Shimadzu), pH meter (HANNA HI2212, Romania), ion chromatography (Metrohm 732 IC Detector, Switzerland), flame photometer (England PFP7, Jenway), and flame atomic absorption spectrometry (YL youngtin8020, South Korea), were used, respectively.

All consumable materials, such as sodium carbonate, sodium bicarbonate, sulfuric acid, sodium chloride anhydrous, the standard solution of calcium and magnesium (1000 ppm), standard solution EDTA (0.01 mM), ammoniacal buffer, and Eriochrome black $\mathrm{T}$ indicator were obtained from Merck Company. Data were analyzed using descriptive statistics and SPSS version 22.

\section{Results}

In Table 1, the specifications of household water treatment systems supplied in Kerman, the period of use of them, and efficacy of these devices for the removal of anions, such as $\mathrm{NO}_{3}{ }^{-}, \mathrm{NO}_{2}{ }^{-}, \mathrm{SO}_{4}{ }^{2-}, \mathrm{HCO}_{3}{ }^{-}$, and $\mathrm{Cl}^{-}$from drinking water in Kerman in 2016 are shown.

The average efficiencies of household water treatment systems studied for the removal of anions, such as $\mathrm{NO}_{3}{ }^{-}$, $\mathrm{NO}_{2}{ }^{-}, \mathrm{SO}_{4}{ }^{2-}, \mathrm{HCO}_{3}{ }^{-}$, and $\mathrm{Cl}^{-}$from drinking water were $66.83,31.50,85,67$, and $68.43 \%$, respectively. Overall, efficiency in the removal of anions (regardless of the nitrite) in all of the household water treatment systems was obtained at more than $66.83 \%$.

In Table 2, the specifications of household water treatment systems supplied in Kerman, the period of use of them, and efficacy of these devices for the removal of cations, such as $\mathrm{Na}^{+}, \mathrm{Ca}^{2+}, \mathrm{Mg}^{2+}$, and total hardness of drinking water in Kerman in 2016 are shown.

The average efficiencies of household water treatment systems studied for the removal of cations, such as $\mathrm{Na}^{+}$, $\mathrm{Ca}^{2+}$, and $\mathrm{Mg}^{2+}$, and total hardness of drinking water were
$80.23,61.20,78.97$, and $69.36 \%$, respectively. Overall, performance of the removal of cations and anions in all of the household water treatment systems was obtained at more than $61.20 \%$.

In Table 3, the average removal efficiencies and concentrations of input and output ions of chloride, sulfate, bicarbonate, calcium, magnesium, sodium, nitrites, nitrates, and total hardness of household water treatment systems supplied in each region of Kerman are shown, and also the results of the $t$ test analysis.

The concentration of ions of chlorine sulfate, nitrate, bicarbonate, calcium, magnesium, sodium, and total hardness had decreased in the output water of water treatment systems. An increase in nitrite production was observed in the output of some devices.

In Table 4, average chemical qualities of water sources in Kerman are reported in terms of various parameters and in comparison with the national Iran standard (ISIRI 2009), Environmental Protection Agency (EPA 2004) and WHO guidelines (WHO 2006).

All parameters of drinking water in Kerman were in the range of Iran's national standard, and of EPA and WHO guidelines, and there is no need for the use of household water treatment systems.

\section{Discussion}

The concentration of ions of chlorine sulfate, nitrate, bicarbonate, calcium, magnesium, sodium, and total hardness had decreased considerably in output treatment systems. But the concentration of output nitrite increased with a significant difference $(p>0.05)$. Since the amount of nitrite in input raw water was less than the allowed limit, increasing the amount of nitrite in the output of these devices is not justified unless one assumes that these devices are not useful to remove nitrite. Also in primary tests, it was determined that free residual chlorine in drinking water in Kerman is in the range of acceptable drinking water standards.

Rajaei et al. (2013) in a study done during 2011-2012 in Iran (Arak) and Sadigh et al. (2015) in a study done during 2013 in Iran (Ardebil) showed that the concentration of nitrite ions in output of household water treatment systems significantly increased, which corresponds with the results of this study. Thus, it can be concluded that household water treatment systems examined do not have the necessary efficiency in removing nitrite. So, in cases when there is a risk of fecal contamination caused by the presence of nitrite, in the knowledge that the device cannot remove this, extra care should be taken. Also, the removal of some minerals creates a disturbance in the ion balance, and may cause an undesirable bitter taste and odor of output water 


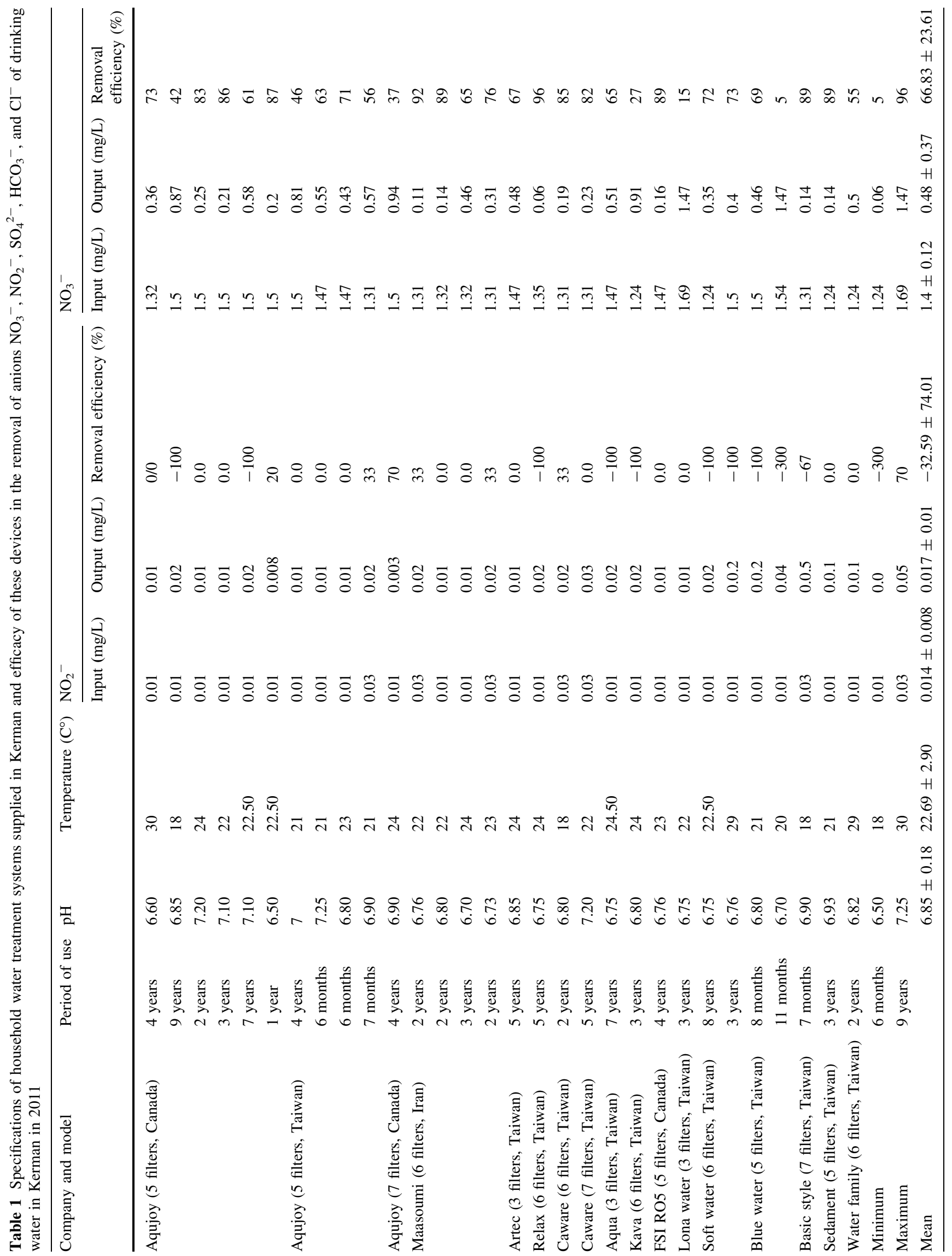




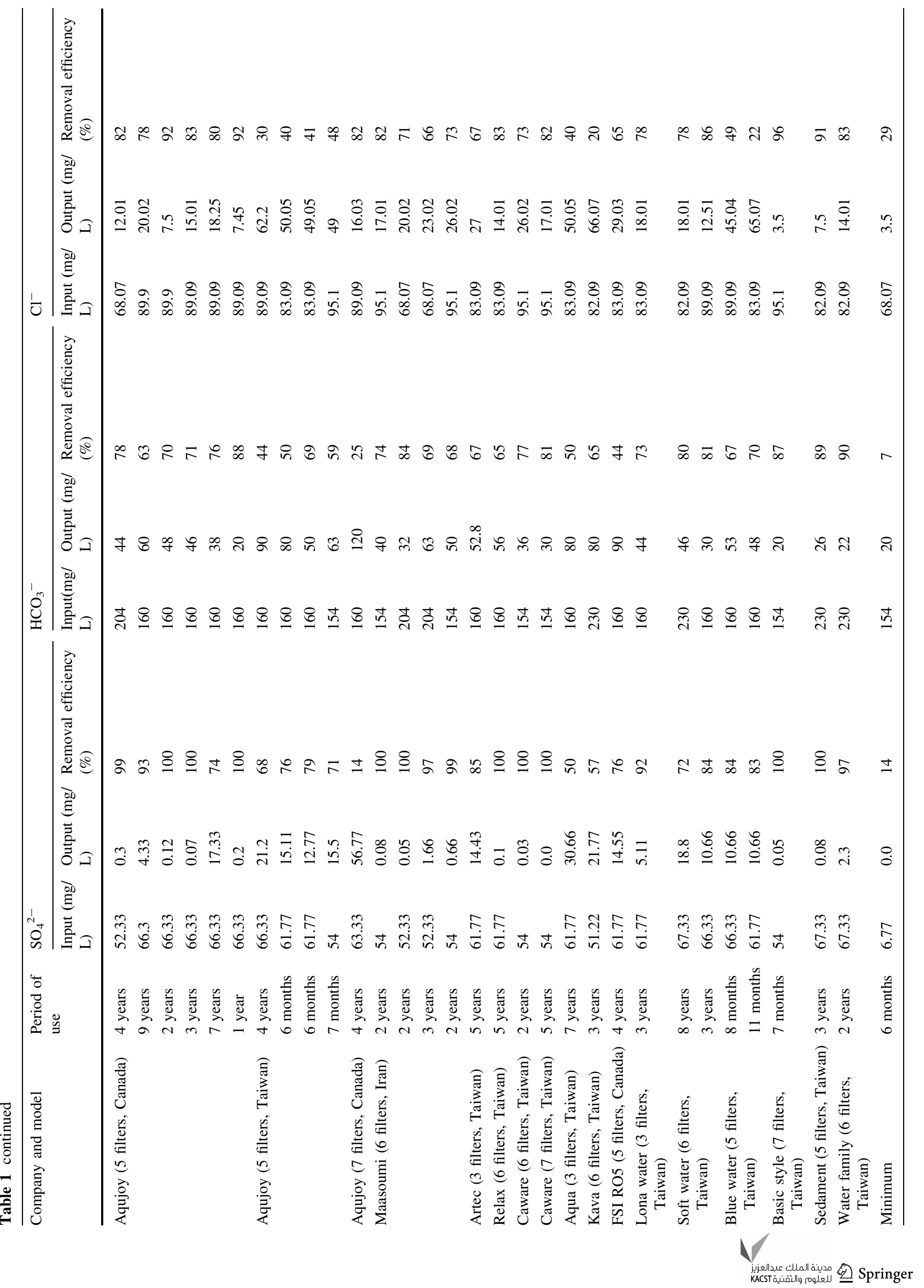




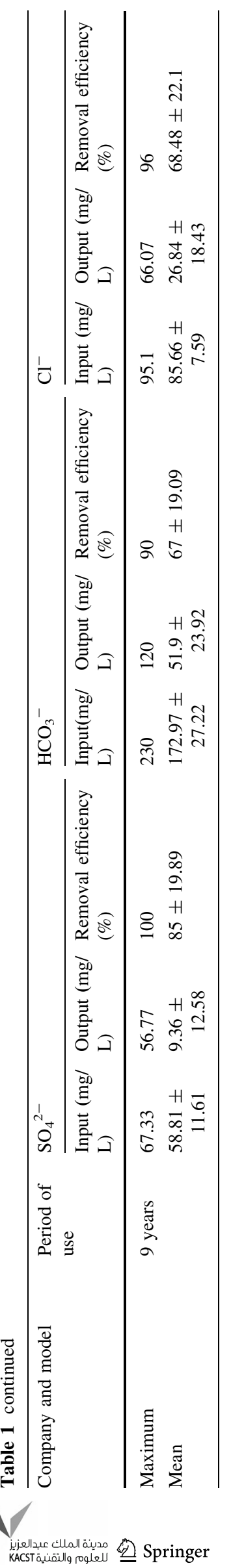

from these devices (Sasidhar and Kumar 2008; Sauvant and Pepin 2002; Savari et al. 2008).

In household water treatment systems, the tested efficiency for the removal of sodium ions was $80.76 \%$, which indicates a high efficiency of these devices to remove sodium from Kerman water. Reduction of this element is useful for patients with renal disease (WHO 2006). Sadigh et al. (2015) in a study done in 2013 in Iran (Ardebil) showed that the concentration of sodium ions of home water treatment systems' output water was reduced significantly, which corresponds to the results of this study. Household water treatment systems tested for removing chloride ions showed an efficiency of $61.20 \%$. The removal of chloride ions in an active carbon black filter purification device caused growth of bacteria in other parts of the water purification device. Household water treatment systems tested efficiency in the removal of nitrate at $83.66 \%$.

Due to the negative health effects of nitrate ions, which are suspected to be carcinogenic (Gilchrist et al. 2010; Gangolli et al. 1994; Manassaram et al. 2006), and to avoid the potential effects of nitrate ions, such as nitrosamine, only where the amount of nitrate from drinking water is more than the limit mentioned in Iran's drinking water standards, EPA, and WHO guidelines, was using water treatment systems recommended (EPA 2004; ISIRI 2009; WHO 2006). Miranzadeh and Rabbani (2010) in a study done in 2008 in Iran (Kashan) reported that the nitrate removal efficiency of water treatment systems was $60.50 \%$, and also Tavangar et al. (2014) in Iran (Bojnord) reported that the nitrate removal efficiency of water treatment systems was $65.50 \%$, which corresponds to the results of this study.

Household water treatment systems tested efficiency in the removal of sulfate ions at $84 \%$. Household water treatment systems tested efficiency in removing magnesium ions at $97.87 \%$. Sadigh and colleagues in a study done in 2013 in Iran (Ardebil) showed that the concentration of magnesium ions of home water treatment systems' output water was reduced significantly, which corresponds to the results of this study. A magnesium deficiency in drinking water increases the risk of cardiovascular disease and stroke (ISIRI 2009; Maier 2003; Morrisa et al. 2008; Sadigh et al. 2015; Saris et al. 2000; Hammer-Sr and Hammer-Jr 2007).

With regard to the concentration of sodium ions, chloride, nitrate, sulfate, and magnesium in drinking water from Kerman being less than the limit mentioned in Iran's drinking water standards, and EPA and WHO guidelines, using these devices is not necessary in Kerman (EPA 2004; ISIRI 2009; WHO 2006).

The great reduction in the amount of ions of sodium, chloride, and magnesium sulfate by household water treatment systems causes other problems in drinking water. 
Table 2 Specifications of household water treatment systems supplied in Kerman and efficacy of these devices in the removal of cations $\mathrm{Na}^{+}$, $\mathrm{Ca}^{2+}, \mathrm{Mg}^{2+}$, and total hardness of drinking water in Kerman in 2016

\begin{tabular}{|c|c|c|c|c|c|c|c|c|c|}
\hline \multirow[t]{2}{*}{ Company and model } & \multirow{2}{*}{$\begin{array}{l}\text { Period of } \\
\text { use }\end{array}$} & \multirow[t]{2}{*}{$\mathrm{pH}$} & \multirow{2}{*}{$\begin{array}{l}\text { Temperature } \\
\left(\mathrm{C}^{\circ}\right)\end{array}$} & \multicolumn{3}{|c|}{ Total hardness } & \multicolumn{3}{|l|}{$\mathrm{Mg}^{2+}$} \\
\hline & & & & $\begin{array}{l}\text { Input }(\mathrm{mg} / \\
\mathrm{L})\end{array}$ & $\begin{array}{l}\text { Output } \\
(\mathrm{mg} / \mathrm{L})\end{array}$ & $\begin{array}{l}\text { Removal } \\
\text { efficiency (\%) }\end{array}$ & $\begin{array}{l}\text { Input } \\
(\mathrm{mg} / \mathrm{L})\end{array}$ & $\begin{array}{l}\text { Output } \\
\text { (mg/L) }\end{array}$ & $\begin{array}{l}\text { Removal } \\
\text { efficiency }(\%)\end{array}$ \\
\hline \multirow{6}{*}{$\begin{array}{l}\text { Aqujoy (5 filters, } \\
\text { Canada) }\end{array}$} & 4 years & 6.60 & 30 & 285 & 44 & 85 & 63 & 9.76 & 85 \\
\hline & 9 years & 6.85 & 18 & 220 & 128 & 42 & 68 & 48 & 29 \\
\hline & 2 years & 7.20 & 24 & 220 & 56 & 75 & 68 & 10.73 & 84 \\
\hline & 3 years & 7.10 & 22 & 220 & 108 & 51 & 68 & 7.8 & 89 \\
\hline & 7 years & 7.10 & 22.5 & 220 & 56 & 75 & 68 & 16.59 & 76 \\
\hline & 1 year & 6.50 & 21 & 220 & 38 & 83 & 68 & 9 & 87 \\
\hline \multirow{4}{*}{$\begin{array}{l}\text { Aqujoy (5 filters, } \\
\text { Taiwan) }\end{array}$} & 4 years & 7.00 & 22.5 & 220 & 48 & 78 & 68 & 20.49 & 70 \\
\hline & 6 months & 7.25 & 21 & 272 & 84 & 69 & 78 & 28.3 & 64 \\
\hline & 6 months & 6.80 & 21 & 272 & 132 & 51 & 78 & 2.92 & 96 \\
\hline & 7 months & 6.90 & 23 & 260 & 36 & 86 & 73 & 19 & 74 \\
\hline $\begin{array}{l}\text { Aqujoy (7 filters, } \\
\text { Canada) }\end{array}$ & 4 years & 6.90 & 24 & 220 & 88 & 60 & 68 & 21.2 & 69 \\
\hline \multirow{4}{*}{$\begin{array}{l}\text { Maasoumi (6 filters, } \\
\text { Iran) }\end{array}$} & 2 years & 6.76 & 22 & 260 & 84 & 68 & 73 & 11.71 & 84 \\
\hline & 2 years & 6.80 & 22 & 285 & 100 & 65 & 63 & 0.97 & 98 \\
\hline & 3 years & 6.70 & 24 & 285 & 128 & 55 & 63 & 28.3 & 55 \\
\hline & 2 years & 6.73 & 23 & 260 & 100 & 62 & 73 & 1.95 & 97 \\
\hline $\begin{array}{l}\text { Artec (3 filters, } \\
\text { Taiwan) }\end{array}$ & 5 years & 6.85 & 24 & 272 & 84 & 69 & 78 & 16.38 & 79 \\
\hline $\begin{array}{l}\text { Relax (6 filters, } \\
\text { Taiwan) }\end{array}$ & 5 years & 6.75 & 24 & 272 & 68 & 75 & 78 & 10.73 & 86 \\
\hline $\begin{array}{l}\text { Caware (6 filters, } \\
\text { Taiwan) }\end{array}$ & 2 years & 6.80 & 18 & 260 & 32 & 88 & 73 & 19.52 & 73 \\
\hline $\begin{array}{l}\text { Caware ( } 7 \text { filters, } \\
\text { Taiwan) }\end{array}$ & 5 years & 7.20 & 22 & 260 & 60 & 77 & 73 & 16.59 & 77 \\
\hline $\begin{array}{l}\text { Aqua (3 filters, } \\
\text { Taiwan) }\end{array}$ & 7 years & 6.75 & 24.5 & 272 & 68 & 75 & 78 & 3.9 & 95 \\
\hline $\begin{array}{l}\text { Kava (6 filters, } \\
\text { Taiwan) }\end{array}$ & 3 years & 6.80 & 24 & 256 & 124 & 52 & 69 & 3.9 & 94 \\
\hline $\begin{array}{l}\text { FSI RO5 (5 filters, } \\
\text { Canada) }\end{array}$ & 4 years & 6.76 & 23 & 272 & 104 & 62 & 78 & 40 & 49 \\
\hline $\begin{array}{l}\text { Lona water (3 filters, } \\
\text { Taiwan) }\end{array}$ & 3 years & 6.75 & 22 & 272 & 36 & 86 & 78 & 3.9 & 95 \\
\hline \multirow{2}{*}{$\begin{array}{l}\text { Soft water (6 filters, } \\
\text { Taiwan) }\end{array}$} & 8 years & 6.75 & 22.5 & 256 & 40 & 84 & 69 & 10.73 & 84 \\
\hline & 3 years & 6.76 & 29 & 220 & 22 & 90 & 68 & 9.64 & 86 \\
\hline \multirow{2}{*}{$\begin{array}{l}\text { Blue water (5 filters, } \\
\text { Taiwan) }\end{array}$} & 8 months & 6.80 & 21 & 220 & 88 & 60 & 68 & 4.88 & 93 \\
\hline & 11 months & 6.70 & 20 & 272 & 190 & 27 & 78 & 36.00 & 84 \\
\hline $\begin{array}{l}\text { Basic style (7 filters, } \\
\text { Taiwan) }\end{array}$ & 7 months & 6.9 & 18 & 260 & 100 & 62 & 73 & 0.97 & 99 \\
\hline $\begin{array}{l}\text { Sedament ( } 5 \text { filters, } \\
\text { Taiwan) }\end{array}$ & 3 years & 6.93 & 21 & 256 & 52 & 80 & 69 & 18.54 & 73 \\
\hline $\begin{array}{l}\text { Water family ( } 6 \\
\text { filters, Taiwan) }\end{array}$ & 2 years & 6.82 & 29 & 256 & 28 & 89 & 69 & 17.56 & 75 \\
\hline Minimum & 6 months & 6.50 & 18 & 220 & 22 & 27 & 63 & 0.97 & 29 \\
\hline Maximum & 9 years & 7.25 & 30 & 285 & 190 & 90 & 78 & 48.00 & 99 \\
\hline Mean & & $\begin{array}{r}6.85 \pm \\
0.18\end{array}$ & $22.69 \pm 2.9$ & $\begin{array}{c}253.17 \pm \\
23.55\end{array}$ & $\begin{array}{r}77.53 \pm \\
39.15\end{array}$ & $69.36 \pm 39.15$ & $\begin{array}{c}71.03 \pm \\
4.92\end{array}$ & $\begin{array}{l}15 \pm \\
11.79\end{array}$ & $78.97 \pm 16.41$ \\
\hline
\end{tabular}


Table 2 continued

\begin{tabular}{|c|c|c|c|c|c|c|c|}
\hline \multirow[t]{2}{*}{ Company and model } & \multirow{2}{*}{$\begin{array}{l}\text { Period of } \\
\text { use }\end{array}$} & \multicolumn{3}{|l|}{$\mathrm{Ca}^{2+}$} & \multicolumn{3}{|l|}{$\mathrm{Na}^{+}$} \\
\hline & & $\begin{array}{l}\text { Input }(\mathrm{mg} / \\
\mathrm{L})\end{array}$ & $\begin{array}{l}\text { Output (mg/ } \\
\text { L) }\end{array}$ & $\begin{array}{l}\text { Removal efficiency } \\
(\%)\end{array}$ & $\begin{array}{l}\text { Input }(\mathrm{mg} / \\
\mathrm{L})\end{array}$ & $\begin{array}{l}\text { Output (mg/ } \\
\text { L) }\end{array}$ & $\begin{array}{l}\text { Removal efficiency } \\
(\%)\end{array}$ \\
\hline \multirow[t]{6}{*}{ Aqujoy (5 filters, Canada) } & 4 years & 171.14 & 33.66 & 80 & 87.91 & 28 & 68 \\
\hline & 9 years & 104.28 & 35.27 & 66 & 80.02 & 48.45 & 39 \\
\hline & 2 years & 104.28 & 40.08 & 62 & 80.02 & 3.35 & 96 \\
\hline & 3 years & 104.28 & 56.11 & 46 & 80.02 & 4.3 & 95 \\
\hline & 7 years & 104.28 & 49.69 & 52 & 80.02 & 36.67 & 54 \\
\hline & 1 year & 104.28 & 41 & 61 & 80.02 & 1.1 & 99 \\
\hline \multirow[t]{4}{*}{ Aqujoy (5 filters, Taiwan) } & 4 years & 104.28 & 52.9 & 49 & 80.02 & 20 & 75 \\
\hline & 6 months & 128.25 & 80.16 & 37 & 100.31 & 15.9 & 84 \\
\hline & 6 months & 128.25 & 48.09 & 63 & 100.31 & 18.01 & 82 \\
\hline & 7 months & 68.93 & 29 & 58 & 83.4 & 16.15 & 81 \\
\hline Aqujoy (7 filters, Canada) & 4 years & 104.28 & 26.11 & 75 & 80.02 & 1.1 & 99 \\
\hline \multirow[t]{4}{*}{ Maasoumi (6 filters, Iran) } & 2 years & 68.93 & 12.9 & 81 & 83.4 & 4.48 & 95 \\
\hline & 2 years & 171.14 & 41.68 & 76 & 87.91 & 6.74 & 92 \\
\hline & 3 years & 171.14 & 34.8 & 80 & 87.91 & 3.2 & 96 \\
\hline & 2 years & 68.93 & 16.87 & 76 & 83.4 & 5.67 & 93 \\
\hline Artec (3 filters, Taiwan) & 5 years & 128.25 & 50 & 61 & 100.31 & 20 & 80 \\
\hline Relax (6 filters, Taiwan) & 5 years & 128.25 & 44.88 & 65 & 100.31 & 3.2 & 97 \\
\hline Caware (6 filters, Taiwan) & 2 years & 68.93 & 44.88 & 35 & 83.4 & 0.7 & 99 \\
\hline Caware (7 filters, Taiwan) & 5 years & 68.93 & 51.3 & 26 & 83.4 & 3.59 & 96 \\
\hline Aqua (3 filters, Taiwan) & 7 years & 128.25 & 43.28 & 66 & 100.31 & 40.56 & 60 \\
\hline Kava (6 filters, Taiwan) & 3 years & 118.63 & 56.11 & 53 & 77.76 & 58.6 & 25 \\
\hline FSI RO5 (5 filters, Canada) & 4 years & 128.25 & 41.68 & 68 & 100.31 & 34.92 & 65 \\
\hline $\begin{array}{l}\text { Lona water (3 filters, } \\
\text { Taiwan) }\end{array}$ & 3 years & 128.25 & 8.01 & 94 & 100.31 & 12.37 & 88 \\
\hline \multirow{2}{*}{$\begin{array}{l}\text { Soft water (6 filters, } \\
\text { Taiwan) }\end{array}$} & 8 years & 118.63 & 33.66 & 72 & 77.76 & 12.37 & 84 \\
\hline & 3 years & 104.28 & 24.88 & 76 & 80.02 & 12.01 & 85 \\
\hline \multirow{2}{*}{$\begin{array}{l}\text { Blue water (5 filters, } \\
\text { Taiwan) }\end{array}$} & 8 months & 104.28 & 43.28 & 58 & 80.02 & 24.78 & 69 \\
\hline & 11 months & 128.25 & 80.16 & 37 & 100.31 & 61.14 & 39 \\
\hline $\begin{array}{l}\text { Basic style (7 filters, } \\
\text { Taiwan) }\end{array}$ & 7 months & 68.93 & 41.68 & 40 & 83.4 & 1 & 99 \\
\hline Sedament ( 5 filters, Taiwan) & 3 years & 118.63 & 51.30 & 57 & 77.76 & 1.1 & 99 \\
\hline $\begin{array}{l}\text { Water family (6 filters, } \\
\text { Taiwan) }\end{array}$ & 2 years & 118.63 & 40.08 & 66 & 77.76 & 20.27 & 74 \\
\hline Minimum & 6 months & 68.93 & 8.01 & 26 & 77.76 & 0.7 & 25 \\
\hline Maximum & 9 years & 171.14 & 80.16 & 94 & 100.31 & 61.14 & 99 \\
\hline Mean & & $\begin{array}{c}113.3 \pm \\
28.1\end{array}$ & $\begin{array}{r}41.5 \pm \\
15.95\end{array}$ & $61.20 \pm 15.96$ & $\begin{array}{c}86.59 \pm \\
8.85\end{array}$ & $\begin{array}{r}16.99 \pm \\
17.53\end{array}$ & $80.23 \pm 20.14$ \\
\hline
\end{tabular}

Household water treatment systems remove useful ions (calcium, sodium, potassium, etc.), which is one of the disadvantages of home water treatment devices. On the other hand, they remove other harmful ions (nitrate, nitrite, etc.). Epidemiological studies have shown that moderateto-high water hardness can be effective in reducing the prevalence of cardiovascular disease (Monarca et al. 2006). Long-term use of treated output water from water treatment systems, because of the reduction of useful minerals in water and hardness, will cause an increased incidence of bone complications from lack of nutrients (Morrisa et al. 2008). Therefore, for the above-mentioned reasons and due to studies in Kerman and other areas, since the quality of drinking water is in accordance with the Iran, and EPA standards and WHO guidelines, the use of water treatment systems devices are not required, and are expensive and not worthwhile. 
Table 3 Concentrations of samples in each region of Kerman and the influence of household water treatment systems in reducing the concentrations of cations and anions in drinking water $(\mathrm{mg} / \mathrm{L})$

\begin{tabular}{|c|c|c|c|c|c|c|c|c|c|}
\hline Parameters & North east & North west & Central & South east & South west & $t$ test & $\begin{array}{l}\text { Degrees } \\
\text { of } \\
\text { freedom }\end{array}$ & $p$ value & $\begin{array}{l}\text { Average of } \\
\text { removal } \\
\text { efficiency }(\%)\end{array}$ \\
\hline \multicolumn{10}{|l|}{$\mathrm{Cl}^{-}(\mathrm{mg} / \mathrm{L})$} \\
\hline Input & 83.09 & 89.09 & 82.09 & 80.02 & 68.07 & \multirow[t]{3}{*}{9.571} & 0.153 & \multirow[t]{3}{*}{0.0} & \multirow[t]{3}{*}{61.2} \\
\hline Output mean & $\begin{array}{r}43.83 \pm \\
24.13\end{array}$ & $\begin{array}{r}22.59 \pm \\
13.41\end{array}$ & $\begin{array}{r}21.82 \pm \\
17.18\end{array}$ & $\begin{array}{r}35.28 \pm \\
26.45\end{array}$ & $\begin{array}{l}29.51 \pm \\
9.41\end{array}$ & & & & \\
\hline $\begin{array}{l}\text { Removal efficiency } \\
\text { mean }\end{array}$ & $\begin{array}{r}47.00 \pm \\
18.01\end{array}$ & $\begin{array}{c}73.00 \pm \\
21.78\end{array}$ & $\begin{array}{r}73.00 \pm \\
24.23\end{array}$ & $\begin{array}{r}56.00 \pm \\
20.14\end{array}$ & $\begin{array}{r}57.00 \pm \\
15.12\end{array}$ & & & & \\
\hline \multicolumn{10}{|l|}{$\mathrm{HCO}_{3}^{-}(\mathrm{mg} / \mathrm{L})$} \\
\hline Input & 160.00 & 160.00 & 230.00 & 190.00 & 204.00 & \multirow[t]{3}{*}{8.104} & 0.709 & \multirow[t]{3}{*}{0.0} & \multirow[t]{3}{*}{73} \\
\hline Output mean & $\begin{array}{r}89.71 \pm \\
27.38\end{array}$ & $\begin{array}{c}51.85 \pm \\
15.18\end{array}$ & $\begin{array}{r}38.60 \pm \\
28.47\end{array}$ & $\begin{array}{r}57.00 \pm \\
23.75\end{array}$ & $\begin{array}{r}34.00 \pm \\
17.83\end{array}$ & & & & \\
\hline $\begin{array}{l}\text { Removal efficiency } \\
\text { mean }\end{array}$ & $\begin{array}{r}44.00 \pm \\
18.26\end{array}$ & $\begin{array}{r}65.00 \pm \\
13.86\end{array}$ & $\begin{array}{c}83.00 \pm \\
20.11\end{array}$ & $\begin{array}{r}70.00 \pm \\
19.43\end{array}$ & $\begin{array}{r}83.00 \pm \\
13.21\end{array}$ & & & & \\
\hline \multicolumn{10}{|l|}{$\mathrm{Na}^{+}(\mathrm{mg} / \mathrm{L})$} \\
\hline Input & 100.31 & 80.02 & 78.76 & 92.00 & 87.91 & \multirow[t]{3}{*}{10.995} & 1.106 & \multirow[t]{3}{*}{0.0} & \multirow[t]{3}{*}{76.8} \\
\hline Output mean & $\begin{array}{r}30.89 \pm \\
21.56\end{array}$ & $\begin{array}{r}30.25 \pm \\
11.36\end{array}$ & $\begin{array}{r}13.80 \pm \\
15.12\end{array}$ & $\begin{array}{r}11.18 \pm \\
18.24\end{array}$ & $\begin{array}{r}8.37 \pm \\
16.32\end{array}$ & & & & \\
\hline $\begin{array}{l}\text { Removal efficiency } \\
\text { mean }\end{array}$ & $\begin{array}{r}64.00 \pm \\
21.84\end{array}$ & $\begin{array}{r}60.00 \pm \\
16.24\end{array}$ & $\begin{array}{r}82.00 \pm \\
22.08\end{array}$ & $\begin{array}{r}88.00 \pm \\
16.95\end{array}$ & $\begin{array}{r}90.00 \pm \\
14.23\end{array}$ & & & & \\
\hline \multicolumn{10}{|l|}{$\mathrm{NO}_{3}{ }^{-}(\mathrm{mg} / \mathrm{L})$} \\
\hline Input & 1.47 & 1.50 & 1.24 & 1.36 & 1.32 & \multirow[t]{3}{*}{7.197} & 7.691 & \multirow[t]{3}{*}{0.0} & \multirow[t]{3}{*}{60.6} \\
\hline Output mean & $0.78 \pm 0.39$ & $0.62 \pm 0.35$ & $0.33 \pm 0.21$ & $0.73 \pm 0.48$ & $0.26 \pm 0.24$ & & & & \\
\hline $\begin{array}{l}\text { Removal efficiency } \\
\text { mean }\end{array}$ & $\begin{array}{r}47.00 \pm \\
21.67\end{array}$ & $\begin{array}{r}57.00 \pm \\
17.23\end{array}$ & $\begin{array}{r}73.00 \pm \\
21.37\end{array}$ & $\begin{array}{r}46.00 \pm \\
16.63\end{array}$ & $\begin{array}{r}80.00 \pm \\
12.22\end{array}$ & & & & \\
\hline \multicolumn{10}{|l|}{$\mathrm{NO}_{2}^{-}(\mathrm{mg} / \mathrm{L})$} \\
\hline Input & 0.01 & 0.01 & 0.01 & 0.01 & 0.01 & \multirow[t]{2}{*}{-1.871} & 10.894 & \multirow[t]{2}{*}{0.098} & \multirow[t]{2}{*}{-} \\
\hline Output mean & $0.01 \pm 0.01$ & $0.01 \pm 0.01$ & $\begin{array}{r}0.02 \pm \\
0.007\end{array}$ & $0.03 \pm 0.02$ & $\begin{array}{c}0.015 \pm \\
0.01\end{array}$ & & & & \\
\hline $\begin{array}{l}\text { Removal efficiency } \\
\text { mean }\end{array}$ & - & - & - & - & - & & & & \\
\hline \multicolumn{10}{|l|}{$\mathrm{SO}_{4}{ }^{2-}{ }_{4}(\mathrm{mg} / \mathrm{L})$} \\
\hline Input & 61.77 & 66.33 & 67.33 & 58.21 & 52.33 & \multirow[t]{3}{*}{9.037} & 1.892 & \multirow[t]{3}{*}{0.0} & \multirow[t]{3}{*}{84} \\
\hline Output mean & $\begin{array}{r}27.13 \pm \\
16.24\end{array}$ & $\begin{array}{r}14.27 \pm \\
10.27\end{array}$ & $0.57 \pm 2.24$ & $6.54 \pm 9.23$ & $1.08 \pm 3.02$ & & & & \\
\hline $\begin{array}{l}\text { Removal efficiency } \\
\text { mean }\end{array}$ & $\begin{array}{r}56.00 \pm \\
17.47\end{array}$ & $\begin{array}{r}78.00 \pm \\
12.67\end{array}$ & $\begin{array}{c}99.00 \pm \\
19.01\end{array}$ & $\begin{array}{r}89.00 \pm \\
16.48\end{array}$ & $\begin{array}{c}98.00 \pm \\
11.78\end{array}$ & & & & \\
\hline \multicolumn{10}{|l|}{ Total hardness (mg/L) } \\
\hline Input & 272.00 & 220.00 & 256.00 & 268.00 & 285.00 & \multirow[t]{3}{*}{9.722} & 0.568 & \multirow[t]{3}{*}{0.0} & 61.8 \\
\hline Output mean & $\begin{array}{c}127.70 \pm \\
27.12\end{array}$ & $\begin{array}{r}89.71 \pm \\
18.92\end{array}$ & $\begin{array}{r}74.80 \pm \\
32.11\end{array}$ & $\begin{array}{c}126.00 \pm \\
21.54\end{array}$ & $\begin{array}{r}68.00 \pm \\
13.24\end{array}$ & & & & \\
\hline $\begin{array}{l}\text { Removal efficiency } \\
\text { mean }\end{array}$ & $\begin{array}{r}53.00 \pm \\
14.68\end{array}$ & $\begin{array}{r}56.00 \pm \\
10.09\end{array}$ & $\begin{array}{c}71.00 \pm \\
14.08\end{array}$ & $53.00 \pm 9.05$ & $\begin{array}{r}76.00 \pm \\
11.21\end{array}$ & & & & \\
\hline $\mathrm{Ca}^{2+}(\mathrm{mg} / \mathrm{L})$ & & & & & & & & & \\
\hline Input & 128.25 & 104.28 & 118.63 & 140.00 & 171.14 & 6.672 & 1.747 & 0.0 & 61.73 \\
\hline Output mean & $\begin{array}{c}67.53 \pm \\
16.21\end{array}$ & $\begin{array}{c}46.94 \pm \\
12.46\end{array}$ & $\begin{array}{c}41.36 \pm \\
14.21\end{array}$ & $52.00 \pm 9.27$ & $\begin{array}{r}35.34 \pm \\
21.74\end{array}$ & & & & \\
\hline $\begin{array}{l}\text { Removal efficiency } \\
\text { mean }\end{array}$ & $\begin{array}{r}47.00 \pm \\
13.41\end{array}$ & $\begin{array}{c}55.00 \pm \\
8.21\end{array}$ & $\begin{array}{r}65.00 \pm \\
15.22\end{array}$ & $\begin{array}{r}63.00 \pm \\
11.02\end{array}$ & $\begin{array}{c}79.00 \pm \\
7.83\end{array}$ & & & & \\
\hline $\mathrm{Mg}^{2+}(\mathrm{mg} / \mathrm{L})$ & & & & & & & & & \\
\hline
\end{tabular}


Table 3 continued

\begin{tabular}{|c|c|c|c|c|c|c|c|c|c|}
\hline Parameters & North east & North west & Central & South east & South west & $t$ test & $\begin{array}{l}\text { Degrees } \\
\text { of } \\
\text { freedom }\end{array}$ & $p$ value & $\begin{array}{l}\text { Average of } \\
\text { removal } \\
\text { efficiency }(\%)\end{array}$ \\
\hline Input & 78.00 & 68.00 & 69.00 & 69.00 & 63.00 & 12.253 & 2.692 & 0.0 & 76.8 \\
\hline Output mean & $\begin{array}{r}26.13 \pm \\
11.36\end{array}$ & $\begin{array}{c}22.93 \pm \\
5.21\end{array}$ & $\begin{array}{c}12.98 \pm \\
8.47\end{array}$ & $7.80 \pm 4.08$ & $9.99 \pm 7.10$ & & & & \\
\hline $\begin{array}{l}\text { Removal efficiency } \\
\text { mean }\end{array}$ & $66.00 \pm 8.21$ & $\begin{array}{c}64.00 \pm \\
9.33\end{array}$ & $\begin{array}{c}81.00 \pm \\
7.11\end{array}$ & $\begin{array}{r}89.00 \pm \\
13.24\end{array}$ & $\begin{array}{c}84.00 \pm \\
7.27\end{array}$ & & & & \\
\hline
\end{tabular}

Table 4 Specifications on drinking water in Kerman in terms of various parameters, and in comparison with the national Iran standard, Environmental Protection Agency (EPA), and WHO guidelines

\begin{tabular}{|c|c|c|c|c|c|c|c|c|c|}
\hline Parameters $(\mathrm{mg} / \mathrm{L})$ & Total hardness & $\mathrm{Cl}^{-}$ & $\mathrm{NO}_{2}^{-}$ & $\mathrm{NO}_{3}{ }^{-}$ & $\mathrm{SO}_{4}{ }^{2-}$ & $\mathrm{HCO}_{3}^{-}$ & $\mathrm{Mg}^{2+}$ & $\mathrm{Ca}^{2+}$ & $\mathrm{Na}^{+}$ \\
\hline Minimum & 220 & 68.07 & 0.01 & 1.24 & 52.33 & 160 & 63 & 104.28 & 78.76 \\
\hline Maximum & 285 & 89.09 & 0.01 & 1.5 & 67.33 & 230 & 78 & 171.14 & 100.31 \\
\hline Mean & 260.2 & 80.47 & 0.01 & 1.38 & 61.19 & 188.80 & 69.40 & 132.46 & 87.80 \\
\hline Standard deviation & 24.74 & 7.71 & 0.0 & 0.11 & 6.61 & 29.95 & 5.41 & 25.28 & 8.89 \\
\hline guidelines WHO & 500 & 250 & 3 & 50 & 250 & 250 & 150 & 200 & 200 \\
\hline Iran standards & 500 & 400 & 3 & 50 & 400 & - & 50 & 250 & 200 \\
\hline EPA & - & 250 & 1 & 10 & 250 & - & - & - & - \\
\hline
\end{tabular}

\section{Conclusion}

Due to good quality, inexpensiveness, and availability of drinking water sources in Kerman, use of household water treatment systems does not have a role in health promotion and reducing disease. In addition, use of household water treatment systems is not recommended because of their removal of useful minerals, such as calcium and magnesium. Initial system purchase price with continued filter replacement costs is prohibitive. In addition, RO filters in household water treatment systems divide water into two parts: water with low mineral concentration and water with high mineral concentration.

Water with high mineral concentration enters directly into sewage output, and can cause more water consumption by water treatment systems. So use of these devices only is recommendable in areas where the drinking water is salty and has high nitrate concentration, and their application in cases where the chemical water quality already complies with desired waste energy standards.

Acknowledgements This research was conducted at the Gastroenterology and Hepatology Research Center in partnership with the Environmental Health Engineering Research Center, and was sponsored by the Vice-Chancellor for Research and Technology of Kerman University of Medical Sciences. A note of appreciation is expressed here to the Vice-Chancellor and to all university staff who provided assistance to make this study possible. At last, thanks goes to Alfred Smith Jr. for editing this article.
Open Access This article is distributed under the terms of the Creative Commons Attribution 4.0 International License (http:// creativecommons.org/licenses/by/4.0/), which permits unrestricted use, distribution, and reproduction in any medium, provided you give appropriate credit to the original author(s) and the source, provide a link to the Creative Commons license, and indicate if changes were made.

\section{References}

Altura BM, Altura BT (1995) Magnesium and cardiovascular biology: an important link between cardiovascular risk factors and atherogenesis. Cell Mol Biol Res 41:347-359

Amiri MC (2007) Principles of water treatment, 22nd edn. Arkan Danesh Publisher, Esfahan (Persian)

Belviso C, Cavalcante F, Gennaro SD, Lettino A, Palma A, Ragone P, Fiore S (2014) Removal of Mn from aqueous solution using fly ash and its hydrothermal synthetic zeolite. J Environ Manage 137:16-22

Chaidez C, Gerba C (2004) Comparison of the microbiologic quality of point-of-use (POU)-treated water and tap water. Int J Environ Health Res 14:253-260

Corma A, Garcia H (2004) Supramolecular host-guest systems in zeolites prepared by ship-in-a-bottle synthesis. Eur J Inorg Chem 2004:1143-1164

Coulliette AD, Enger KS, Weir MH, Rose JB (2013) Risk reduction assessment of waterborne Salmonella and Vibrio by a chlorine contact disinfectant point-of-use device. Int J Hyg Environ Health 216:355-361

Eaton AD, Clesceri LS, Rice EW, Greenberg AE, Franson MAH (2005) standard Methods for the Examination of Water \& 
Wastewater. American Public Health Association, American Water Works Association, Water Environment Federation, Washington

Environmental Protection Agency US (EPA) (2004) Overview of contaminations and their potential Health effects. Edition of the Drinking water standard and Health Advisors, Washington, DC, pp 1-20

Esmailiyan A, Nezamzadeh A (2010) Evaluation of contaminant adsorbed sulfate anion potentiometric method using synthetic zeolite 13X. J Sci Islam Azad Univ (JSIAU) 20:21-28

Gangolli SD, van den Brandt PA, Feron VJ, Janzowsky C, Koeman JH, Speijers GJ, Spiegelhalder B, Walker R, Wisnok JS (1994) Assessment; Nitrate, nitrite and N-nitroso compounds. Eur J Pharmacol 292:1-38

Ghee TM, Steel E (1991) Water supply and sewerage, 6th edn. McGraw Hill, New York, pp 158-170

Gilchrist M, Winyard PG, Benjamin N (2010) Review; dietary nitrate-good or bad? Nitric Oxide 22:104-109

Hammer-Sr M, Hammer-Jr M (2007) Water and wastewater technologies, 6th edn. Willy, New York, pp 137-158

Hortiguela LG, Pariente JP, Garcia R, Chebude Y, Diaz I (2013) Natural zeolites from Ethiopia for elimination of fluoride from drinking water. Sep Purif Technol 120:224-229

Institute of Standards and Industrial Research of Iran (ISIRI) (2009) Drinking water: physical and chemical specifications. Standard No. 1053

Luby SP, Mendoza C, Keswick BH, Chiller TM, Hoekstra M (2008) Difficulties in bringing point-of-use water treatment to scale in rural Guatemala. Am J Trop Med Hyg 78:382-387

Maier J (2003) Low magnesium and atherosclerosis: an evidencebased link. Mol Aspects Med 24:137-146

Malakootian M, Ehrampoush MH, Hossaini H, Mazandarani MP (2015) Acetaminophen removal from aqueous solutions by TiO2-X photo catalyst. Toloo e Behdasht 14:200-213

Malakootian M, Mazandarani MP, Hossaini H, Ehrampoush MH (2016a) Preparation and characterization of $\mathrm{TiO} 2$ incorporated $13 \mathrm{X}$ molecular sieves for photocatalytic removal of acetaminophen from aqueous solutions. Process Saf Environ Prot 104:334-345

Malakootian M, Sepehr MN, Bahraini S, Zarrabi M (2016b) Capacity of natural and modified zeolite with cationic surfactant in removal of antibiotic tetracycline from aqueous solutions. Koomesh 17:779-788

Manassaram D, Backer L, Moll D (2006) A review of nitrates in drinking water: maternal exposure and adverse reproductive and developmental outcomes. Environ Health Perspect 114:320-327

Mao RLV, Xiao S, Ramsaran A, Yao J (1994) Selective removal of silicon from zeolite frameworks using sodium carbonate. J Mater Chem 1994:605-610

Miranzadeh MB, Rabbani DK (2010) Chemical quality evaluation for the inlet and outlet water taken from of the desalination plants utilized in Kashan during 2008. Feyz 14:120-125

Monarca S, Donatob F, Zerbinib I, Calderonc R, Craund G (2006) Review of epidemiological studies on drinking water hardness and cardiovascular diseases. Eur J Cardiovasc Prev Rehabil 13:495-506

Morrisa RW, Walkera M, Lennona LT, Shapera AG, Whincupb PH (2008) Hard drinking water does not protect against cardiovascular disease: new evidence from the British Regional Heart Study. Eur J Cardiovasc Prev Rehabil 15:185-189

Mwabi JK, Adeyemo FE, Mahlangu TO, Mamba BB, Brouckaert BM, Swartz CD, Offringa G, Mpenyana-Monyatsi L, Momba MNB (2011) Household water treatment systems: a solution to the production of safe drinking water by the low-income communities of Southern Africa. Phys Chem Earth 36:1120-1128

Rajaei MS, Salemi Z, Karimi B, Zadeh MJG, Mashayekhi M (2013) Effect of household water treatment systems on the physical and chemical quality of water in 2011-2012. Arak Med Univ J (AMUJ) 16:26-36

Sadigh A, Nasehi F, Fataei E, Aligadri M (2015) Investigating the efficiency of home water treatment systems to reduce or eliminate water quality parameters in the city of Ardabil in 1392. J Health 6:458-469

Saris N, Mervaala E, Karppanen H, Khawaja J, Lewenstam A (2000) Magnesium. An update on physiological, clinical and analytical aspects. Clin Chim Acta 294:1-26

Sasidhar P, Kumar SV (2008) Assessment of groundwater corrosiveness for unconfined aquifer system at Kalpakkam. Environ Monit Assess 145:445-452

Sauvant M, Pepin D (2002) Drinking water and cardiovascular disease. Food Chem Toxicol 40:1311-1325

Savari J, Jaafazadeh N, Hassani A, Abadi GSK (2008) Surveys the physical and chemical quality of Ahvaz city drinking water. J Sch Public Health Inst Public Health Res 5:75-85

Tavangar A, Naimi N, Alizade H, Ghochani HT, Ghorbanpour R (2014) Evaluation of water treatment systems' performance available in Bojnurdciry during 2013. J North Khorasan Univ Med Sci (JNKUMS) 5:1107-1119

Tobin R, Smith D, Lindsay J (1981) Effects of activated carbon and bacteriostatic filters on microbiological quality of drinking water. Appl Environ Microbiol 41:646-651

Wang S, Peng Y (2010) Natural zeolites as effective adsorbents in water and wastewater treatment. Chem Eng J 156:11-24

World Health Organization (WHO) (2006) Guideline values for drinking water quality. 3rd edn. Geneva

Yari AR, Safdari M, Hadadian 1, Babakhani H (2007) The physical, chemical and microbial quality of treated water in Qom's desalination plants. Qom Univ Med Sci J 1:45-54

Yusof AM, Keat LK, Ibrahim Z, Majid ZA, Nizam NA (2010) Kinetic and equilibrium studies of the removal of ammonium ions from aqueous solution by rice husk ash-synthesized zeolite $\mathrm{Y}$ and powdered and granulated forms of mordenite. J Hazard Mater 174:380-385

Zhou L, Boyd C (2014) Total ammonia nitrogen removal from aqueous solutions by the natural zeolite, mordenite: a laboratory test and experimental study. Aquaculture 432:252-257 